\title{
Siirt İlindeki Küçükbaş Hayvancılık İşletmelerinin Yapısal Durumu
}

\author{
Galip BAKIR ${ }^{*}$ (D) Nazire MİKAİL \\ Siirt Üniversitesi, Ziraat Fakültesi, Zootekni Bölümü, Siirt, Türkiye \\ (*Sorumlu yazar e-mail: galipbakir@ hotmail.com) \\ DOI: 10.17097/ataunizfd.411087 \\ Geliş Tarihi (Received Date): 22.03.2018 \\ Kabul Tarihi (Accepted Date): 17.12.2018
}

\begin{abstract}
ÖZ: Bu çalışma, Siirt yöresinin küçükbaş hayvancıllk işletmelerinin mevki, rakım, hayvan sayısı ve ırkı, destek uygulamasından yararlanma, sütün değerlendirilmesi gibi yapısal ve işletmecilerin demografik, birlik ve kooperatife üyelik gibi sosyal durumlarını belirlemek amacıyla yapılmıştır. Araştırma materyalini Siirt il merkezi ve 6 ilçesinde gayeli örnekleme yöntemine göre belirlenen 286 işletmede yapılan anket verileri oluşturmaktadır. İșletmelerin \%8.7'si il merkezinde olup, yoğunluk Pervari (\%25.5), Şirvan (\%19.9) ve Eruh (\% 18.2) ilçesinde bulunmaktadır. İşletmelerin bulunduğu köylerin rakımları ortalama $1134 \mathrm{~m}$ olup, işletmelerin \% 44.8 'i dağ köyünde, \% 29'u yamaç, \%24.5'i ova köyünde bulunmaktadır. Yörede işletmecilerin sadece \%1.7'si göçer hayvanc1lık yapmaktadır. Ortalama 47.3yaşında olan işletmecilerin \%26.2'si okuma yazma bilmemekte, \%61.2'si ilkokul mezunu, \%10.1'i ortaokul mezunu ve \%2.4'ü ise lise mezunudur. Her işletme ortalama 146.15 küçükbaş hayvan ve 38.27 da araziye sahip olup, 70 işletmenin arazisi bulunmamaktadır. İșletmelerde hayvansal üretime çocuk etkisinin oranı $\% 71$, kadın etkisinin oranı ise $\% 90.2$ olarak önemli bulunmuştur $(\mathrm{p}<0.01)$. Yetiştiricilerin \%97.2'sinin mevcut ırklardan memnun oldukları, \%40.6'sının sadece hayvancılık ile uğraştıkları, \%59.4'ünün ise ticaret, bitkisel üretim ve kamusal alanda çalıştıkları tespit edilmiştir. Siirt ili küçükbaş hayvancılı̆̆ı, genel olarak dağ köylerinde, ilkokul tahsiline sahip ve hayvancılık için yeterli arazisi olmayan, çocuk ve kadınların üretime katkısının yoğun olduğu işletmelerden oluşmaktadır. Bölgede hayvancılığın daha rasyonel yapılması ve üretimin artırılması için, eğitim düzeyi yüksek gençlerin hayvancılığa teşvik edilmesi, üreticilerin yetiştirme teknikleri konusunda eğitilmesi ve işletmelerin teknik olarak iyileştirilmesi gerekmektedir.
\end{abstract}

Anahtar Kelimeler: Küçükbaş hayvancılık, Yapısal durum, Siirt, Türkiye

\section{Structural Characteristics of Sheep and Goat Farms in Siirt Province}

\begin{abstract}
This study was aimed to investigates structural and demographic and social characteristic of sheep and goat farms in Siirt province which are; location of farm, altitude, animal race and number, government support, being member of cooperative and unity. Research material was obtained from a survey which carried out in 286 farms located in Siirt city center and 6 districts. As for location, just $8.7 \%$ of farms were in Centrum, however most of the farms as their intensity were being in Pervari (25.5\%), Şirvan (19.9\%) and Eruh (18.2\%) districts respectively. The average altitude of the villages where farms located was $1134 \mathrm{~m}$ altitude, and $44.8 \%$ of farms were mountain villages, $29 \%$ in slope villages and $24.5 \%$ in lowland villages. Only $1.7 \%$ of the farms were doing migratory livestock. The average age of the farmers was 47.3 years old. The educational status rate was observed as $61.2 \%$ graduates from primary school and followed by illiterate $(26.2 \%)$, graduates from secondary school $(10.1 \%)$, but only $2.4 \%$ of the farmers were graduated from high school. The average number of sheep and goat per farm was 146.15 . The average land ownership per farm was 38,27 da. and 70 farms did not have any land ownership. It was found that the contribution of children and women on production was significant $(\mathrm{p}<0.01)$. The contribution ratio of children and the female was $71 \%$ and $90.2 \%$ respectively. It was found that $97.2 \%$ of the farmers were satisfied with the breed they raised, $40.6 \%$ of the farmers were just doing livestock production, while $59.4 \%$ were working in the trade, crop production, and government jobs. Structurally farms in Siirt province is generally located in mountain villages, average land owned is $38.27 \mathrm{da}$. Most of the farmers educated at primary level and intensive child and women contribution to the productionare common. It was determined that in order to do a more rational animal husbandry and to increase the production in these farms, more educated people encouraged and technical improvement and technical knowledge for farmers are required.
\end{abstract}

Keywords: Sheep and goat farms, Structural characteristic, Siirt, Turkey

\section{GíRiş}

Küçükbaş hayvan yetiştiriciliği tarımsal üretimin verimsiz olduğu arazilere kısa sürede uyum göstermesi ve bu alanları değerlendirerek et, süt, yapağı, kıl, tiftik, deri gibi ürünlere dönüştürmesi açısından Siirt ili için önemli bir sektördür. Koyun ve keçiler yetersiz mera ve elverişsiz iklim koşullarına uyum sağlama yetenekleriyle ön plana çıkmaktadır. Meraları en iyi şekilde değerlendirebilen ve yılın her döneminde merayı kullanabilen küçükbaş hayvancılık faaliyeti Türkiye'nin coğrafi yapısına son derece uygundur (Anonim, 2013).

Çağlayan ve Durmuş, (2010) bitkisel üretim yapılacak yer şekillerinin sınırlı olması Diyarbakır ilinde yer alan işletmecileri hayvancıllığa yönelttiğgini ve küçükbaş hayvancılık nüfusun büyük bir bölümünün temel geçim kaynağı durumunda olduğunu bildirmektedir. Havzada küçükbaş hayvancılıkla ilgilenen aileler genellikle yarı göçebe hayvancılık yapmaktadır. Göçerler sürekli bir yerleşim yerleri olmayan, yazı yaylalarda, kış mevsimini ise kışlaklarda geçiren, y1l boyunca sürüleriyle dolaşan insanlardır. Yazları Bitlis, Hakkâri, Van ve Muş yaylalarında, kışları ılıman iklim bölgelerinde ve tüm yılı çadırlarında geçiren göçerler, elde ettikleri hayvansal ürünleri buralarda değerlendirirler. Göçerlerin yoğunluğu nedeniyle, Siirt'te hayvan sürüleri hareketliliği yaşanır. Her yıl 2 milyon dolayında küçükbaş hayvan yaylak-kışlak 
arasında gidip gelir. Siirt ilini de kapsayan Dicle havzasının kuzeyindeki vadiler boyunca sıralanan yerleşmelerde özellikle kıl keçisi yetiştiriciliğine dayalı küçükbaş hayvancılık faaliyetleri ön plandadır.

GAP Bölgesinde hem kendi ihtiyaçlarını gidermek, hem de tarımsal gelirlerine katkı sağlamak amacıyla işletmelerde küçükbaş hayvancılığa yer veren tarım işletmelerinin ekonomik yönden incelenmesi ve sorunlarının saptanması ve bu sorunların giderilmesi için alınabilecek önlemlerin tespiti büyük önem taşımaktadır (Dellal vd., 2001). Hayvancılık işletmelerinin yapısal durumlarının belirlenmesi, il, bölge ve ülke bazında yapılacak hem bilimsel hem de stratejik çalışmalara alt yapı teşkil edecektir.

$\mathrm{Bu}$ çalışmada, Siirt yöresinin küçükbaş hayvancılık işletmelerinin mevki, rakım, hayvan sayıs1 ve 1rk1, destek uygulamasından yararlanma, sütün değerlendirilmesi gibi yapısal ile işletmecilerin demografik, birlik ve kooperatife üyelik gibi sosyal durumlarını belirlemek amacıyla yapılmıştır. Elde edilen sonuçlar, Siirt ilinde yapılacak olan küçükbaş hayvancılık ile ilgili alt yapı çalışmalarına ve stratejik planlamalara 1 şı tutacaktır.

\section{MATERYAL VE METOT}

Araştırma materyalini, Siirt ili Merkez ve ilçelerinde bulunan 286 adet küçükbaş hayvancılık işletmelerinde yüz yüze yapılan anket verileri ve işletmelerde yapılan gözlemler oluşturmuştur. Araştırmada, küçükbaş hayvan varlığı bakımından ilçeleri temsil eden köyler, bölgede görev yapan veteriner hekimlerin görüşü alınarak gayeli örnekleme yöntemi ile belirlenmiştir. Siirt yöresine kayıtlı göçer ve kalıcı küçükbaş hayvancılık işletmelerinden Mayıs-Aralık 2015 döneminde anket yolu ile veriler toplanmıştır. Anket çalışmalarında örnek hacminin belirlenmesinde, populasyonun en az \%3'ü (Yamane, 2010) veya \%10'unun (Cochran, 1977) alınmasının yeterli olacağı bildirilmiştir. Siirt Gıda Tarım ve Hayvancılık İl Müdürlüğü kayıtlarından alınan toplam işletme sayısı dikkate alınarak, 4773 işletmeden 286'sında(\%6) araştırmanın amacına uygun olarak hazırlanmış anket formları kullanılarak; Siirt ili Merkez ve Pervari, Şirvan, Eruh, Kurtalan, Baykan ve Tillo olmak üzere 6 ilçeye bağlı köylerde tesadüfi örnekleme yöntemiyle anket çalışması yürütülmüştür. Anketlerin köylere dağılımında \% oranlar kullanılmıştır. Anket uygulamasından elde edilen verilerin analizi SPSS 21.0 paket programı kullanılarak yapılmıştır (Yazıcıoğlu ve Erdoğan, 2004).

\section{BULGULAR VE TARTIŞMA}

Anket yapılan işletmelerin mevki ve köy tiplerine dağılımı Çizelge 1 'de verilmiştir. Araştırma kapsamına alınan işletmeler dağ köyü (\%44.8), yamaç-ova köyü (\%29) ve ova (\%24.5) köylerinde bulunurken, işletmelerin yalnızca \%1.7'si göçer koyunculuk yapmaktadır. Ceyhan vd. (2015)'nin koyunculuk işletmeleri üzerine yaptıkları çalışmada, koyunculuk yapma şekillerini \%40.6 yayla, \%38.5 yerleşik ve sadece \%1.1'ni göçer olarak bildirmektedir.

İşletmelerin il veya ilçe merkezine uzaklığı 1-60 $\mathrm{km}$ arasında değişmekle birlikte, ortalama 16.27 km'dir. İşletmelerin bulunduğu merkezlerin rakımları ortalama $1134 \mathrm{~m}$ iken, 682-1370 m arasında değişmektedir (Çizelge 2). İşletmelerin \%75.5'i 842 rakımın üstünde yayla ve dağlık alanlarda bulunmaktadır.

Çizelge 1. İşletmelerin mevki ve köy tipine göre dağılımı

\begin{tabular}{|c|c|c|c|c|c|c|c|c|c|c|c|c|c|}
\hline & \multicolumn{8}{|c|}{ Mevki } & \multicolumn{5}{|c|}{ Köy tipi } \\
\hline & $\frac{N}{\stackrel{N}{d}}$ & 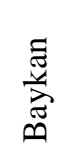 & 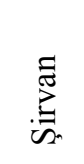 & D & 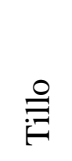 & 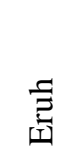 & 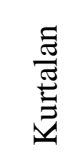 & $\frac{\text { E }}{\frac{\pi}{2}}$ & 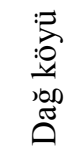 & 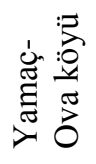 & 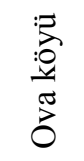 & 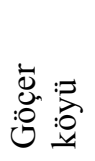 & $\frac{\Xi}{\frac{\pi}{a}}$ \\
\hline Adet & 25 & 27 & 57 & 73 & 11 & 52 & 41 & 286 & 128 & 83 & 70 & 5 & 286 \\
\hline$\%$ & 8.7 & 9.4 & 19.9 & 25.5 & 3.8 & 18.2 & 14.3 & 100 & 44.8 & 29.0 & 24.5 & 1.7 & 100 \\
\hline
\end{tabular}

Çizelge 2. İşletmelerin il ve ilçe merkezine uzaklık ve rakıma göre dağılımı

\begin{tabular}{|c|c|c|c|c|c|c|c|c|c|c|}
\hline & \multicolumn{5}{|c|}{ Merkeze uzaklık (km) } & \multicolumn{5}{|c|}{ Rakım (m) } \\
\hline & $9<$ & $10-15$ & $16-25$ & $26>$ & Toplam & $842<$ & $843-1121$ & $1122-1369$ & $1370>$ & Toplam \\
\hline Adet & 128 & 83 & 70 & 5 & 286 & 70 & 73 & 51 & 92 & 286 \\
\hline$\%$ & 44.8 & 29 & 24.5 & 1.7 & 100 & 24.5 & 25.5 & 17.8 & 32.2 & 100 \\
\hline
\end{tabular}


İşletmelerin ilçe merkezlerine olan uzaklıkları mevki bazında incelenmiştir. Buna göre, Kurtalan, Tillo ve Merkezdeki işletmelerin tamamına yakını ilçe Merkezine 1-20 km uzaklıkta yer alırken, bunun aksine Pervari ve Baykan gibi ilçelerde ise işletmelerin \%50'den fazlasının merkeze 21-40 km uzak mesafede yer aldığı belirlenmiştir. Bu iki ilçenin topoğrafik yapısının vadilerden oluşması ve ilçe merkezinde yeterli meranın bulunmaması nedeniyle, işletmeler genellikle yaylalarda yer almaktadır. Bu nedenle iki ilçede hayvancılık yayla hayvancılığı şeklinde yapılmaktadır.
İşletmecilerin eğitim durumlarına bakıldığında, en fazla (\%61.2) ilkokul ve en az ise (\%2.4) lise mezunu iken, \%26.2'sinin de okuryazar olmadığ tespit edilmiştir. İşletmecilerin yaşları 20-84 yıl arasında değişmekte olup, işletmecilerin yaş ortalamasının 47 y1l olduğu belirlenmiştir. Hayvancılık yapılan süre 11 ile 41 yıl arasında değişmekte olup, ortalama 22.6 yıldır. İşletmecilerin en yoğun olduğu tahsil, yaş ve hayvancılık deneyim grupları sırası ile ilkokul $(\% 61,2), 37-48$ y1l $(\% 34,6)$ ve 21-30 y1l $(\% 30,1)$ olarak bulunmuştur (Çizelge 3$)$.

Çizelge 3. İşletmecilerin tahsil durumu, yaş ve hayvancılık yaptıkları sürenin dağılımı

\begin{tabular}{|c|c|c|c|c|c|c|c|c|c|c|c|c|c|c|c|}
\hline & \multicolumn{5}{|c|}{ Tahsil } & \multicolumn{5}{|c|}{ Yaş } & \multicolumn{5}{|c|}{ Hayvancılık süresi } \\
\hline & $\frac{y}{\partial}$ & $\begin{array}{l}\bar{\Xi} \\
\overline{0} \\
. ٍ\end{array}$ & 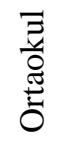 & $\stackrel{\mathscr{A}}{\Xi}$ & $\frac{\Xi}{\stackrel{\Xi}{0}}$ & $\begin{array}{l}0 \\
\text { dí } \\
\stackrel{b}{v}\end{array}$ & $\frac{\infty}{\frac{\infty}{m}}$ & $\begin{array}{l}\text { مे } \\
\text { ó }\end{array}$ & 巳 & $\frac{\Xi}{\frac{\pi}{a}}$ & $\stackrel{\text { ㄱ }}{\stackrel{1}{=}}$ & 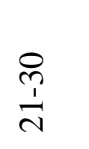 & $\frac{\stackrel{P}{i}}{m}$ & $\frac{+}{\forall}$ & $\frac{\Xi}{\Xi}$ \\
\hline Adet & 75 & 175 & 29 & 7 & 286 & 56 & 99 & 78 & 53 & 286 & 60 & 86 & 71 & 69 & 286 \\
\hline$\%$ & 26.2 & 61.2 & 10.1 & 2.4 & 100 & 19.6 & 34.6 & 27.3 & 18.5 & 100 & 21 & 30.1 & 24.8 & 24.1 & 100 \\
\hline
\end{tabular}

Urfa ilinde yapılan bir araştırmada, en genç işletmeci 25 , en yaşlı işletmeci yaşının 80 yaşında olup, ortalama işletmeci yaşı ise 47.8 yıl olarak belirlenmiştir. Koyun yetiştiriciliği yapılan sürenin en az 10 en çok 65 ve ortalama 29 yıl olduğu bildirilmiştir (Karadaş, 2018a).

Ceyhan vd. (2015)'i Niğde ilinde koyunculuk işletmeleri üzerine yaptıkları çalışmada, işletmecilerin \%68.8'i ilkokul, \%14.5'i ortaokul, $\% 12.5$ 'i lise ve \%4.2'sinin okuryazar olduğunu belirlemişlerdir. Niğde ilindeki bu çalışmada; yayla koyunculuğu yapanların oranı \%40.6 iken, yerleşik koyunculuk yapanlar \%38.5, yerleşik ve yayla koyunculuğu yapanlar \%19.8 ve göçer koyunculuk yapan işletmelerin oranının \% 1.0 olduğu ifade edilmiştir. Koyunculuk yapmayı işletmecilerin $\% 86.5$ 'i babadan atadan ögrrendiklerini, \% 5.2'si İ/İlçe Müdürlüklerinde bulunan teknik elemanlardan, \%3.1'i kendi kendine öğrendiğini bildirmişlerdir.

Van ilinde küçükbaş hayvan işletmelerinde yapılan bir çalışmada ise, yetiştiricilerin öğrenim durumları ilkokul (\%46.1), ortaokul (\%17.8), lise (\%7.0), üniversite (\%0.76) mezunu olarak bildirilirken, okuryazar olmayanların oranı \% 1.01 olarak tespit edilmiştir (Karakuş ve Akkol, 2013). Çanakkale ilinde koyun yetiştiricilerinin \%65'inin ilkokul, \%10'unun ortaokul, \%25'inin ise lise mezunu olduğu bildirilmiştir (Koyuncu vd., 2006). Diğer yandan Bilginturan ve Ayhan (2009), Burdur ilinde koyunculuk yapanların \%90.2'sinin ilkokul, $\% 7.7$ 'sinin lise, \%0.5'inin yüksekokul mezunu olduğunu, \%1.5'inin ise okuryazar olmadığını bildirmişlerdir.

$\mathrm{Bu}$ araştırmada incelenen işletmelerde bulunan ortalama küçükbaş hayvan sayısı 146.15 baş olup, 5-1800 baş arasında değişmektedir. Sı̆̆ıı sayısı ise 1-200 baş aralığında değişmekle birlikte ortalama 6.74 olup, 1-200 baş aralığında değişmektedir. Araştırma kapsamındaki işletmelerde bulunan toplam küçükbaş hayvan sayısı 41.798 baş iken, toplam büyükbaş hayvan sayısı ise 951 baş olarak tespit edilmiştir.

İşletmelerde bulunan küçükbaş hayvan sayısı işletmelerin bulunduğu mevkiye göre farklı dağılım göstermiştir(Çizelge 4). Buna göre, 50 baş ve daha az hayvana sahip işletmeler, genel dağılım içerisinde \%37.8'lik paya sahip iken, 500 baş ve üzeri hayvana sahip işletmelerin oranı ise $\% 6.3$ olarak bulunmuştur. Eruh ve Baykan ilçesinde bulunan işletmelerin $\% 55.8$ ve $\% 51.9$ 'unun $50 \leq$ baş ve daha az hayvana sahip oldukları ve merkezde bulunan işletmelerin ise $\% 28$ 'inin 500 baş ve üzeri hayvana sahip oldukları belirlenmiştir. Küçükbaş hayvanlar arasında yörede en yoğun bulunan 1 rk \%81.1 oranıyla Hamdani melezi olmuştur. Baykan ilçesi hariç diğer ilçelerde Hamdani melezi yoğunluktadır. Baykan'da ise Hamdani melezinin oran $\% 48.1$ iken bunu \% 44.4 oranıla İvesi ırkı ve \% 7.4 oranıyla k1 keçisi melezi izlemiştir. İşletmecilerin \%97.2'si yetiştirmiş oldukları ırklardan memnun olduklarını, memnun olmayan işletmecilerin ise, sebep olarak verim sorunu ve yemden yararlanmanın az olmasını belirtmişlerdir. 
Çizelge 4. İşletmelerde bulunan küçükbaş varlığı ve irklara göre dağılımı

\begin{tabular}{|c|c|c|c|c|c|c|c|c|c|c|c|}
\hline \multirow{2}{*}{ Mevki } & & \multicolumn{5}{|c|}{ Hayvan say1s1** } & \multirow[b]{2}{*}{ Toplam } & \multicolumn{3}{|c|}{ Irk dağılımı** } & \multirow[b]{2}{*}{ Toplam } \\
\hline & & $50 \leq$ & $51-100$ & $101-250$ & $251-500$ & $500 \geq$ & & $\begin{array}{c}\text { K1l keçisi } \\
\text { melezi }\end{array}$ & İvesi & $\begin{array}{c}\text { Hamdani } \\
\text { melezi }\end{array}$ & \\
\hline \multirow{2}{*}{ Merkez } & Adet & 5 & 2 & 6 & 5 & 7 & 25 & 2 & 0 & 23 & 25 \\
\hline & $\%$ & 20.0 & 8.0 & 24.0 & 20.0 & 28.0 & 100.0 & 8.0 & 0.0 & 92.0 & 100.0 \\
\hline \multirow{2}{*}{ Baykan } & Adet & 14 & 5 & 4 & 2 & 2 & 27 & 2 & 12 & 13 & 27 \\
\hline & $\%$ & 51.9 & 18.5 & 14.8 & 7.4 & 7.4 & 100.0 & 7.4 & 44.4 & 48.1 & 100.0 \\
\hline \multirow{2}{*}{ Şirvan } & Adet & 17 & 22 & 12 & 4 & 2 & 57 & 7 & 2 & 48 & 57 \\
\hline & $\%$ & 29.8 & 38.6 & 21.1 & 7.0 & 3.5 & 100.0 & 12.3 & 3.5 & 84.2 & 100.0 \\
\hline \multirow{2}{*}{ Pervari } & Adet & 26 & 24 & 20 & 2 & 1 & 73 & 15 & 0 & 58 & 73 \\
\hline & $\%$ & 35.6 & 32.9 & 27.4 & 2.7 & 1.4 & 100.0 & 20.5 & 0.0 & 79.5 & 100.0 \\
\hline \multirow{2}{*}{ Tillo } & Adet & 3 & 3 & 2 & 2 & 1 & 11 & 0 & 0 & 11 & 11 \\
\hline & $\%$ & 27.3 & 27.3 & 18.2 & 18.2 & 9.1 & 100.0 & 0.0 & 0.0 & 100.0 & 100.0 \\
\hline Sayılar & Adet & 29 & 13 & 5 & 2 & 3 & 52 & 11 & 0 & 41 & 52 \\
\hline Eruh & $\%$ & 55.8 & 25.0 & 9.6 & 3.8 & 5.8 & 100.0 & 21.2 & 0.0 & 78.8 & 100.0 \\
\hline \multirow{2}{*}{ Kurtalan } & Adet & 14 & 14 & 9 & 2 & 2 & 41 & 3 & 0 & 38 & 41 \\
\hline & $\%$ & 34.1 & 34.1 & 22.0 & 4.9 & 4.9 & 100.0 & 7.3 & 0.0 & 92.7 & 100.0 \\
\hline \multirow{2}{*}{ Toplam } & Adet & 108 & 83 & 58 & 19 & 18 & 286 & 40 & 14 & 232 & 286 \\
\hline & $\%$ & 37.8 & 29.0 & 20.3 & 6.6 & 6.3 & 100.0 & 14.0 & 4.9 & 81.1 & 100.0 \\
\hline
\end{tabular}

**p $<0.01$

İşletmelerde işçilik genellikle (\%94.4) çocuk ve kadınlar dahil aile bireyleri tarafından karşılanırken, gerekli olduğu durumlarda dışarıdan işçi alındığı bildirilmiştir. İşletmede çalışan sayısı en fazla \%39.2 oranıyla 1-2 kişilik grupta iken, bunu \%34.3 oranıyla 3-4 kişilik grup izlemektedir. Bu durum işletmelerin tipik aile işletmeciliği yapısında yürütüldüğünü göstermektedir. Ceyhan vd. (2015) tarafından yapılan çalışmada, iş̧̧iliğin genellikle (\%63.5) aile içinden sağlandığını, işletmelerin \%33.3'ü yıl boyu ve \% 3.1'inin işlerin yoğun olduğu dönemde dışarıdan iş̧̧i çalıştırdığını bildirmektedir. Aynı araştırıcılar, aile içinden iş̧iliğin genellikle (\%96.9) erkeklerden oluştuğunu; koyunculuk yapma süresinin ortalama 25.7 yıl olduğunu bildirmektedir. Ayrıca, işletme başına ortalama koyun sayısının 314.5 baş olduğunu ve işletmelerde koyundan başka ortalama 7.9 baş büyükbaş hayvan olduğunu bildirmektedir.

Bolu yöresinde Şişman vd. (2009) tarafından yapılan bir çalışmada, işletmelerin \%55'inde küçükbaş hayvancıllğın yanında büyükbaş hayvancılığında yapıldığı ve hayvan sayısının da işletmelerin \%69'unda 200 başın altında olduğu bildirilmektedir. Niğde'de yapılan çalışmada, koyun rrk1 olarak işletmelerin \%99'unda Akkaraman, $\% 1$ 'inde Merinos melezi yetiştirildiği bildirilmektedir (Ceyhan vd., 2015). Çeşitli illerde yapılan araştırmada işletme başına ortalama koyun sayısını Ceyhan vd. (2015) 314.5 baş; Paksoy vd. (2006) 123 baş; Bilginturan ve Ayhan (2009) 112.8 baş olarak bildirmektedir. Van'da yapılan araştırmada işletmelerde esas olarak Akkaraman (\%57.58), Norduz (\%23.21) ve Karakaş (\%11.0) koyunları ile
K1l keçisi (\%79.68) ve Norduz keçisi (\%20.32) yetiştirildiği bildirilmektedir (Karakuş ve Akkol, 2013).

Çalışmada incelenen işletmelerin \% 16'sında küçükbaş hayvan yanında ev ihtiyacını karşılamak ve gelirin devamlılığı açısından büyükbaş hayvan da yetiştirilmektedir. Bu işletmelerde, sığır mevcudunun $\% 55.9$ 'u 1-2 baş iken, bunu \%22.1 oranıla 3-4 baş hayvana sahip işletmeler izlemektedir. İşletmelerdeki sığırların irk dağılımına bakıldığında, en fazla (\%47.9) kültür ırkı yer alırken, bunu \%46.6 oranıla yerli ve $\% 5.5$ oranıla melez irklar izlemektedir. Kültür sığır ırkları arasında en fazla Esmer (\%29.4) ve Simental (\%16.6) yer alırken, yerli sığır ırkları arasında ise en fazla Güney Anadolu Kırmızısı (\% 26.4) ve Yerlikara (\%17.7) yer almaktadır. İşletmelerde en az yetiştirilen Doğu Anadolu Kırmızısı ve Siyah Alaca irklarının olması dikkat çekici bulunmuştur (Çizelge 5).

İşletmelerde çobanlık, yemleme ve sağım gibi işlerde üretime çocuk ve kadın katkısı araştırılmıştır. Buna göre işletmelerde çocuk ve kadın etkisinin \%71 ve $\% 90.2$ olduğu bulunmuştur. $\mathrm{Bu}$ durum, işletmelerde üretime çocuk ve kadınların yoğun bir şekilde destek verdiklerini göstermektedir. Hayvancılığa yeni başlayan işletmeciler, işletmelerini daha uzak yerlerde kurarken, baba mesleği olarak yapanların \%69.1'inin ilçelere daha yakın mesafelere işletmelerini kurdukları tespit edilmiştir. Yeni işletme kuranların uzak mesafeyi tercih etmeleri, ilçe merkezinde yerin olmaması yanında hem yayla imkanından yararlanmak hem de yeterli sermayesinin olmamasından kaynaklandığı düşünülmektedir. 
İşletmelerin \%32.5'inin kaba yem ihtiyacını karşılamak için arazisi bulunmamaktadır. Arazisi olan işletmelerin arazi varlığ 1-600 da arasında değişim gösterirken, ortalama arazi miktarı ise 38.27 da'dır. İşletmelerdeki toplam arazi varlığı içinde sulanabilir arazi varlığı, işletme başına ortalama 2.96 da'dır. Bu durum yörenin coğrafik şartlarının sulu tarıma izin vermemesinin yanında, işletmelerin hayvancılık faaliyetlerini daha çok meraya dayalı olarak yaptıklarını göstermektedir.

Çizelge 5. İşletmelerde bulunan sığır varlığı ve ırklara göre dağılımı

\begin{tabular}{|c|c|c|c|c|c|c|c|c|c|c|c|c|c|c|c|c|}
\hline & \multicolumn{5}{|c|}{ Hayvan sayısı (baş) } & \multicolumn{4}{|c|}{ Irk dağılım } & \multicolumn{7}{|c|}{ Irk adları } \\
\hline & $\stackrel{I}{\longrightarrow}$ & $\stackrel{+}{\text { ஸे }}$ & in & + & $\frac{\Xi}{\frac{\pi}{a}}$ & $\begin{array}{l}:= \\
\vdots \\
\vdots \\
\vdots\end{array}$ & $\frac{N}{N^{N}}$ & $\overline{\bar{D}}$ & $\frac{\Xi}{\frac{\Xi}{2}}$ & 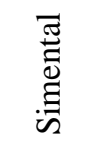 & $\begin{array}{l}\underset{\mathbb{Z}}{\mathbb{Z}} \\
\dot{\boldsymbol{s}}\end{array}$ & 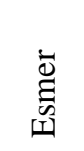 & $\underset{\mho}{\mathbb{U}}$ & 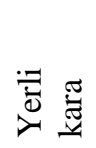 & $\frac{N}{\Sigma}$ & $\frac{\Xi}{\frac{\pi}{0}}$ \\
\hline Adet & 81 & 32 & 15 & 17 & 145 & 78 & 9 & 76 & 163 & 27 & 5 & 48 & 46 & 28 & 9 & 163 \\
\hline$\%$ & 55.9 & 22.1 & 10.3 & 11.7 & 100.0 & 47.9 & 5.5 & 46.6 & 100 & 16.6 & 3.1 & 29.4 & 28.2 & 17.7 & 5.5 & 100 \\
\hline
\end{tabular}

İşletmelerin sorun ve beklentilerine bakıldığında, işletmelerin \%51.1'inin hayvancılığa verilen desteğin yetersiz olduğunu ve artırılması gerektiğini, \%20'sinin su sorunu olduğunu tespit edilmiştir. Bunlara ilaveten işletmelerin \%15.6's1 üretim yetersizliği ve fiyat yüksekliğinden oluşan kaba ve kesif yem sıkıntısı olduğunu ve kaba yem üretiminin artırılması destek beklediklerini ve kesif yem fiyatının düşürülmesi için çözüm beklediklerini bildirmişlerdir. Ayrıca birkaç işletme ise hayvanlarına çoban bulamadıklarını ve bu konuda yetkililerden destek beklediklerini bildirmişlerdir.

Ceyhan vd. (2015) Niğde koyunculuk işletmelerinde önemli görülen sorunların yem fiyatlarının pahalı olması, meraların yetersiz ve kalitesiz olması ve hayvan hastalıkları olduğunu, Karadaş (2018b) Hakkari yöresindeki koyunculuk işletmelerinin tamamında yem fiyatlarının yüksek olmasının ciddi sorun oluşturduğunu bildirmiştir.

İşletme sahiplerinin \%86.4 gibi büyük bir kısmı koyunculuğu babadan öğrendikleri belirlenmiştir. Yine işlemecilerin \%82.3'ü yapacak başka işleri olmadığından hayvancılığın tek geçim kaynağı olduğunu ve işletmecilerin \%10.4'ü de bu işi sevdiği için yaptığını bildirmişlerdir. Ayrıca, işletmecilerin tamamına yakını (\%94.2) yöre şartları gereği hayvancılı̆̆ yıllarda teşviklerinde katkısıyla hayvancılığa yeni başlayanların oranı sadece \% 5.8 olarak bulunmuştur.

Niğde'de yapılan araştırmada, işletmecilerin koyun yetiştiriciliğini yapma nedeni olarak, \% 82.3'ünün tek geçim kaynağı olması, \%10.4'ünün sevdiği için yapması ve \% 7.3'ünün aile ihtiyaçları için bu iş kolunu yapması olduğu bildirilmiştir (Ceyhan vd., 2015). Şahinli (2014) işletmecilerin koyunculuğa başlama nedenlerini baba mesleği olması (\%64), ek gelir elde etme (\%20) ve hayvancılığa yeni başlama (\%10) olduğunu bildirmiştir. Van'da yapılan araştırmada ise işletmelerin küçükbaş hayvancılık yapma nedenleri tek geçim kaynağı olması (\%60.84), ev ihtiyacını karşılamak (\%15.02), ek gelir elde etmek $(\% 11.62)$ ve alışkanlık (\%12.52) olarak bildirilmektedir (Karakuş ve Akkol, 2013). Bilginturan ve Ayhan (2009) başka bir geliri olmaması nedeniyle işletmecilerin \%64.4'ünün hayvan yetiştiriciliği yaptıklarını tespit etmişlerdir.

Araştırmada işletmecilerin \%40.6'sının sadece hayvancılık yaptıkları, diğerlerinin ise hayvancılığa ilaveten ticaret (\%2.4) bitkisel üretim (\%31.5) ve kamusal alanda çalışma (\%25.5) gibi uğraşları olduğu tespit edilmiştir. Sadece hayvancılığın yoğun olarak yapıldığı işletmeler Merkez (\%56) ve Kurtalan'da (\%51.2) bulunmaktadır. Hayvancılık dışındaki uğraşlardan bitkisel üretimin en fazla yapıldığı ilçeler Tillo (\%81.8) ve Eruh (\%61.5) iken, kamusal alanda çalışma gibi hayvancılık dışında başka bir işle uğraşan işletmecilerin en yoğun olduğu $(\% 46.6)$ ilçe Pervari'dir. Üretilen sütün $\% 95.5$ 'i peynire dönüştürülmekte veya süt olarak fabrika dişında aracılara pazarlanırken, üreticilerin \%2.4'ü sütü fabrikaya vermektedir. Merkez dışındaki işletmelerin çoğunluğu sütü kendileri pazarlarken, merkezdeki işletmelerin \%16'sı fabrikaya vermektedir (Çizelge $6)$.

Tamer ve Sarı̈̈zkan (2017), yetiştiricilerin \%49.2'sinin kendi ihtiyaçlarını karşılamak için sütü peynir yaptıklarını ve fazlasını pazarladıklarını ifade etmişlerdir. Dönmez (2008) ise işletmelerde üretilen sütün \%31.2 oranında işletmecilerin kendi ihtiyaçlarını için kullandıkları ve \%6.4'ünün sütü mandıralara pazarladıklarını bildirmektedir.

İşletmelerin devletten aldıkları hayvancılık destek uygulamaları incelenmiş olup, devletten alınan en yoğun desteğin \%81.8 oranı ile anaç koyun ve keçi desteğidir. Bunun yanında, az sayıda da olsa işletmelerin süt ve yem bitkileri desteğinden yararlandığı beyan edilmiştir. Buna karşın, işletmelerin \% 14'nün hiçbir devlet desteğinden yararlanmadıkları belirlenmiştir (Çizelge 7) 
Çizelge 6. Hayvancılık dışında başka işle uğraşma ve sütü değerlendirmenin mevkiye göre değişimi

\begin{tabular}{|c|c|c|c|c|c|c|c|c|c|c|}
\hline \multirow[b]{2}{*}{ Mevki } & & \multicolumn{4}{|c|}{ Başka işle uğraşma** } & \multirow[b]{2}{*}{ Toplam } & \multicolumn{3}{|c|}{ Sütü değerlendirme** } & \multirow[b]{2}{*}{ Toplam } \\
\hline & & Ticaret & $\begin{array}{c}\text { Tarımın } \\
\text { diğer kolları }\end{array}$ & Memur & $\begin{array}{c}\text { Sadece } \\
\text { hayvancilık }\end{array}$ & & $\begin{array}{c}\text { Kooperatife } \\
\text { satarak }\end{array}$ & Fabrika & $\begin{array}{c}\text { Kendi } \\
\text { pazarlıyor }\end{array}$ & \\
\hline \multirow{2}{*}{ Merkez } & Adet & 2 & 9 & 0 & 14 & 25 & 1 & 4 & 20 & 25 \\
\hline & $\%$ & 8.0 & 36.0 & 0.0 & 56.0 & 100.0 & 4.0 & 16.0 & 80.0 & 100.0 \\
\hline \multirow{2}{*}{ Baykan } & Adet & 1 & 6 & 11 & 9 & 27 & 3 & 0 & 24 & 27 \\
\hline & $\%$ & 3.7 & 22.2 & 40.7 & 33.3 & 100.0 & 11.1 & 0.0 & 88.9 & 100.0 \\
\hline \multirow{2}{*}{ Şirvan } & Adet & 0 & 10 & 21 & 26 & 57 & 0 & 0 & 57 & 57 \\
\hline & $\%$ & 0.0 & 17.5 & 36.8 & 45.6 & 100.0 & 0.0 & 0.0 & 100.0 & 100.0 \\
\hline \multirow{2}{*}{ Pervari } & Adet & 2 & 8 & 34 & 29 & 73 & 0 & 0 & 73 & 73 \\
\hline & $\%$ & 2.7 & 11.0 & 46.6 & 39.7 & 100.0 & 0.0 & 0.0 & 100.0 & 100.0 \\
\hline \multirow{2}{*}{ Tillo } & Adet & 0 & 9 & 1 & 1 & 11 & 0 & 0 & 11 & 11 \\
\hline & $\%$ & 0.0 & 81.8 & 9.1 & 9.1 & 100.0 & 0.0 & 0.0 & 100.0 & 100.0 \\
\hline \multirow{2}{*}{ Eruh } & Adet & 2 & 32 & 2 & 16 & 52 & 1 & 0 & 51 & 52 \\
\hline & $\%$ & 3.8 & 61.5 & 3.8 & 30.8 & 100.0 & 1.9 & 0.0 & 98.1 & 100.0 \\
\hline \multirow{2}{*}{ Kurtalan } & Adet & 0 & 16 & 4 & 21 & 41 & 1 & 3 & 37 & 41 \\
\hline & $\%$ & 0.0 & 39.0 & 9.8 & 51.2 & 100.0 & 2.4 & 7.3 & 90.2 & 100.0 \\
\hline \multirow{2}{*}{ Toplam } & Adet & 7 & 90 & 73 & 116 & 286 & 6 & 7 & 273 & 286 \\
\hline & $\%$ & 2.4 & 31.5 & 25.5 & 40.6 & 100.0 & 2.1 & 2.4 & 95.5 & 100.0 \\
\hline
\end{tabular}

Destek uygulamasına mevki bazında bakıldığında ise, desteklerden en fazla yararlanan ilçenin \%98.1 oranıyla Eruh ve \%97.6 oranıla Kurtalan ilçeleri olurken, en fazla yararlanamayan ilçe ise \% 38.4 oranı ile Pervari ilçesi olmuştur. Destek uygulamasından yararlanma bakımından ilçeler arasındaki fark çok önemli $(\mathrm{p}<0.01)$ bulunmuştur (Çizelge 7).

İşletmelerin \%89.9'u hayvan yetiştiriciliği ve diğer konularla ilgili teknik bilgi almaktadır. İşletmecilerin teknik bilgi alım yeri olarak çoğunlukla (\%97) tarım il ve ilçe müdürlükleridir. Buna karşın
Eruh ilçesinde bulunan işletmecilerin \%13.5'i hayvancılıkla ilgili bilgilenmeyi aile büyüklerin edindikleri tespit edilmiştir. İşletmecilerin \%92.3'ünün herhangi bir birlik veya kooperatife üye olduğu, sadece \% 7.7'sinin herhangi bir üyeliği olmadığı tespit edilmiştir. İşletmecilerin hayvancılıkla ilgili herhangi bir birlik veya kooperatife üyeliği ile mevki arasındaki ilişki çok önemli $(\mathrm{p}<0.01)$ bulunmuştur. Buna göre, Tillo ilçesindeki işletmecilerin kooperatif veya birliğe üyeliği oranı $\% 72.7$ iken, bu oran Eruh'taki işletmecilerde \%100'dür (Çizelge 8).

Çizelge 7. İşletmelerin destek uygulamalarından yararlanmalarının mevkiye göre değişimi

\begin{tabular}{|c|c|c|c|c|c|c|}
\hline \multirow{2}{*}{ Mevki } & & \multicolumn{4}{|c|}{ Destek uygulamasi $^{* *}$} & \multirow[b]{2}{*}{ Toplam } \\
\hline & & Süt & Yem bitkileri & Anaç koyun-keçi & Faydalanmadi & \\
\hline \multirow{3}{*}{ Merkez } & Adet & 5 & 0 & 20 & 0 & 25 \\
\hline & $\%$ & 20 & 0 & 80 & 0 & 100 \\
\hline & Adet & 2 & 0 & 23 & 2 & 27 \\
\hline \multirow[t]{2}{*}{ Baykan } & $\%$ & 7.4 & 0 & 85.2 & 7.4 & 100 \\
\hline & Adet & 0 & 0 & 50 & 7 & 57 \\
\hline \multirow[t]{2}{*}{ Şirvan } & $\%$ & 0 & 0 & 87.7 & 12.3 & 100 \\
\hline & Adet & 0 & 1 & 44 & 28 & 73 \\
\hline \multirow[t]{2}{*}{ Pervari } & $\%$ & 0 & 1.4 & 60.3 & 38.4 & 100 \\
\hline & Adet & 0 & 1 & 9 & 1 & 11 \\
\hline \multirow[t]{2}{*}{ Tillo } & $\%$ & 0 & 9.1 & 81.8 & 9.1 & 100 \\
\hline & Adet & 1 & 0 & 50 & 1 & 52 \\
\hline \multirow[t]{2}{*}{ Eruh } & $\%$ & 1.9 & 0 & 96.2 & 1.9 & 100 \\
\hline & Adet & 2 & 0 & 38 & 1 & 41 \\
\hline Kurtalan & $\%$ & 4.9 & 0 & 92.7 & 2.4 & 100 \\
\hline \multirow{2}{*}{ Toplam } & Adet & 10 & 2 & 234 & 40 & 286 \\
\hline & $\%$ & 3.5 & 0.7 & 81.8 & 14.0 & 100 \\
\hline
\end{tabular}


Çizelge 8. İşletmecilerin teknik bilgi kaynağı ve birlik ile kooperatif üyelik durumu

\begin{tabular}{|c|c|c|c|c|c|c|c|}
\hline \multirow[b]{2}{*}{ Mevki } & & \multicolumn{2}{|c|}{ Teknik bilgi kaynağ $1 * *$} & \multirow[b]{2}{*}{ Toplam } & \multicolumn{2}{|c|}{$\begin{array}{c}\text { Birlik ve kooperatife } \\
\text { üyelik }\end{array}$} & \multirow[b]{2}{*}{ Toplam } \\
\hline & & $\begin{array}{c}\text { Tarım } \\
\text { müdürlüğü }\end{array}$ & $\begin{array}{c}\text { Aile } \\
\text { büyükleri }\end{array}$ & & Evet & Hayır & \\
\hline \multirow{2}{*}{ Merkez } & Adet & 17 & 1 & 18 & 20 & 5 & 25 \\
\hline & $\%$ & 94.4 & 5.6 & 100 & 80 & 20 & 100 \\
\hline \multirow{2}{*}{ Baykan } & Adet & 27 & 0 & 27 & 24 & 3 & 27 \\
\hline & $\%$ & 100 & 0 & 100 & 88.9 & 11.1 & 100 \\
\hline \multirow{2}{*}{ Şirvan } & Adet & 55 & 2 & 57 & 53 & 4 & 57 \\
\hline & $\%$ & 96.5 & 3.5 & 100 & 93 & 7 & 100 \\
\hline \multirow{2}{*}{ Pervari } & Adet & 73 & 0 & 73 & 71 & 2 & 73 \\
\hline & $\%$ & 100 & 0 & 100 & 97.3 & 2.7 & 100 \\
\hline \multirow{2}{*}{ Tillo } & Adet & 10 & 0 & 10 & 8 & 3 & 11 \\
\hline & $\%$ & 100 & 0 & 100 & 72.7 & 27.3 & 100 \\
\hline \multirow{2}{*}{ Eruh } & Adet & 32 & 5 & 37 & 52 & 0 & 52 \\
\hline & $\%$ & 86.5 & 13.5 & 100 & 100 & 0 & 100 \\
\hline \multirow{2}{*}{ Kurtalan } & Adet & 41 & 0 & 41 & 36 & 5 & 41 \\
\hline & $\%$ & 100 & 0 & 100 & 87.8 & 12.2 & 100 \\
\hline \multirow{2}{*}{ Toplam } & Adet & 255 & 8 & 263 & 264 & 22 & 286 \\
\hline & $\%$ & 97 & 3 & 100 & 92.3 & 7.7 & 100 \\
\hline
\end{tabular}

$* * \mathrm{p}<0.01$

Bingöl ili Merkez ve ilçelerinde küçükbaş hayvancılık üzerine yapılan çalışmada; yetiştiricilerin \%72'sinin yenilik ve bilgiye ulaşmada il ve ilçe müdürlüklerini, \%19'unun damızlık koyun keçi yetiştiricileri birliklerini ve \%13'ünün ise TV, gazete, internet gibi sanal medya kaynaklarını kullandıkları belirlenmiştir (Karakaya ve Kızıloğlu, 2014).

Niğde ilinde Ceyhan vd. (2015)'i tarafindan yapılan çalışmada, işletmecilerin \%97.9'unun Damızlık Koyun ve Keçi Yetiştiricileri birliğine üye, $\% 2.1$ 'i üye olmadığını; işletmecilerin \%86.5'inin, koyunculuk yapmayı atadan öğrendikleri, \% 5.2'si İl/İlçe müdürlüklerinden öğrendikleri, \% 3.1'inin kendi kendine, \%5.2'sinin ise İl/İlçe Müdürlükleri ya da Damızlık Koyun ve Keçi Yetiştiricileri Birliğinden öğrendikleri belirlenmiştir. Dellal vd. (2002) ise, Güneydoğu Anadolu illerinde yaptıkları çalışmada, işletmecilerin \%66.9'unun yetiştiricilik ile ilgili bilgileri ebeveynlerinden aldıklarını ve \%28.7'sinin ise tarım müdürlüklerinden aldıklarını bildirmişlerdir.

Ceyhan vd. (2015), Niğde ilinde yaptıkları çalışmada Damızlık koyun ve keçi yetiştiricileri birliğine üye olanların oranını \%97.9 olarak tespit etmişlerdir. Ardahan ilinde yapılan çalışmada bulunan orandan (\%74.2) yüksek bulunmuştur (Ayvazoğlu vd. 2015). Güneydoğu Anadolu bölgesinde yapılan araştırmada, iller genelinde incelenen küçükbaş hayvancilık işletmecilerin \%92.8'i herhangi bir yetiştirici örgütüne üye olmadıklarını bildirirken, \%7.2'si üye olduklarını bildirmişlerdir (Dellal vd. 2002).

Siirt ilinde küçükbaş hayvancılık genellikle yüksek rakımlı dağ ve yamaç merkeze uzak köylerde bulunan işletmelerde yapıldığ 1 ve işletmecilerin demografik profilinin ise, genellikle 50 yaş civarında ve eğitim düzeylerini ise ilkokul ve okuryazar olmadıkları belirlenmiştir. Yörede yaşayan eğitim düzeyi yüksek gençlerin hayvancılığa teşvik edilmesi ve bu yönde yapılan teşviklerin artırılması hayvancılığın geliştirilmesi açısından önem arz etmektedir. Ayrıca, işletme başına düşen arazi miktarının düşük olması, dengeli bir hayvan beslemenin yapılamayacağını ve yörede meraya dayalı hayvancılığın zorunlu olarak yapıldığını göstermektedir. Yetiştiricilerin ürettikleri sütün tamamına yakınını peynir olarak değerlendirdikleri, verilecek eğitim ve sağlanacak mandıra gibi imkânlar ile peynir kalitesinin ve çeşidini artırma imkânı öngörülmektedir.

\section{SONUÇ}

Siirt ili bulunduğu coğrafya ve topoğrafik yapısı nedeniyle hayvancılık için önemli bir potansiyele sahiptir. Siirt ili küçükbaş hayvancılık işletmelerinin yapısal durumunu belirlemek amaciyla yapılan bu araştırma sonuçlarına göre, işletmelerin yoğun olarak dağ köylerinde bulunduğu, işletmecilerin ortalama 50 yaş civarında oldukları, çoğunluğun eğitim düzelerinin okuryazar olmayan ve ilkokul olan işletmecilerden oluştuğu belirlenmiştir. Ancak ilde koyunculuk yapan işletmeciler arasında üniversite mezunu olmaması, ülkemizde koyunculuğun hayvancılık iş kolu olarak değerlendirilmemesi bunun sebeplerinden biri olabilir.

İşletme başına ortalama 150 baş hayvan düşen işletmelerde, çocuk ve kadınların iş gücü ile üretime 
katkılarının yoğun olduğu tespit edilmiştir. Bu işletmelerde üretimin gerçekleşmesinde kadın ve çocukların katkısının yanında hayvancılığı meslek haline getirecek ve sürekliliğini sağlayacak olan genç nüfusun eğitilmesinin daha isabetli olacağı düşünülmektedir. Ayrıca, Siirt ili küçükbaş hayvancılığı, genel olarak dağ köylerinde, ilkokul tahsiline sahip ve hayvancılık için yeterli arazisi olmayan, çocuk ve kadınların üretime katkısının yoğun olduğu işletmelerden oluşmaktadır.

İşletmelerde çoban genellikle aile içinden sağlanmaktadır. Ancak kimi işletmeler dışarıdan kiralık çobana çalıştırmak istese de ücretin yüksek olması nedeniyle karşılayamadıkları belirlenmiştir. $\mathrm{Bu}$ nedenle devletten çoban desteği bekledikleri tespit edilmiştir.

İşletmelerde kaliteli ve sağlıklı süt üretimini artırmak için bu konuda köylerde eğitim toplantılarının düzenlenmesi gerekliliği anlaşılmıştır. Hastalıkların yayılmasını önlemeye yönelik etkin bir sağlık koruma programına ihtiyaç duyulmaktadır. Koruyucu hekimlik uygulamaları konusunda yetiştiricilere eğitimler verilmesi önemli görülmüş̧ür.

Yörede \%14 oranında işletmelerin hayvancılık için verilen destekten yararlanmadıkları, bu oranın Pervari ilçesinde \%38.4 olduğu belirlenmiştir. Üretimin artırılması için önemli katkısı olan bu desteğin yörede yaygınlaştırması için çalışmalar yapılmalıdır. Bölgede hayvancılığın daha rasyonel yapılması ve üretimin artırılması için, eğitim düzeyi yüksek gençlerin hayvancılığa teşvik edilmesi, üreticilerin yetiştirme teknikleri konusunda eğitilmesi ve işletmelerin teknik olarak iyileştirilmesi gerekmektedir.

Sonuç olarak, koyun yetiştiricilerinin en önemli sorunları arasında yem fiyatlarının pahalı olması, ürün fiyatlarının düşük, meraların yetersiz ve kalitesiz olması ile birlikte hayvan hastalıkları yer almaktadır. Koyunculuğu cazip hale getirebilmek için ürün pazarlama fiyatlarının artması, meraların ıslahı ve kalitesinin iyileştirilmesi, yem bitkileri ekiliş alanının mümkün olduğunca artırılması ve uygun kredi olanaklarının sağlanması yörede koyunculuğun geliştirilmesi ve üretimin artırılması için önemli olduğu anlaşılmıştır.

\section{TEŞEKKÜR}

Bu çalışma 2014 Sİ̈ZZİR-09 nolu Proje ile BAP tarafından desteklenmiştir. Ayrıca, bu çalışmaya katkılarından dolayı Gıda, Tarım ve Hayvancılık İlçe Müdürlüğü çalışanlarına teşekkür ederiz.

\section{KAYNAKLAR}

Anonim, 2013. T.C. Niğde Valiliği İl Gıda Tarım ve Hayvancilık Müdürlüğü Brifing 2013. http://nigde.tarim.gov.tr/B.
Ayvazoğlu-Demir, P., Adıgüzel-Işık, S., Aydın, E., Yazıcı, K., Ayvazoğlu, C., 2015. Ardahan ilinde koyun yetiştiriciliğinin sosyo-ekonomik önemi. Van Vet. J., 26(3): 141-146.

Bilginturan, S., Ayhan,V., 2009.Burdur İli Damızlık Koyun ve Keçi Yetiştiriciler Birliği Üyesi Koyunculuk İşletmelerinin Yapısal Özellikleri ve Sorunları Üzerine Bir Araştırma. Hayvansal Üretim 50(1): 1-8.

Ceyhan, A., Şekeroğlu, A., Ünalan, A., Çınar, M., Serbester, U., Akyol, E., Y1lmaz, E., 2015. Niğde ili Koyunculuk İşletmelerinin Yapısal Özellikleri ve Sorunları Üzerine Bir Araştırma, KSÜ Doğa Bil. Derg., 18(2): 60-68.

Cochran, W.G., 1977. Sampling Techniques. 3rd Edition. John Wileyand Sons. New York.

Çağlıyan, A., Durmuş, E., 2010. Diyarbakır havzası ve yakın çevresinde küçükbaş hayvancılık. Fırat Üniv. Sosyal Bil. Derg., 20: 29-56.

Çiçek, A., Erkan, O., 1996. Tarım ekonomisinde araştırma ve örnekleme yöntemleri. GOPÜni. Ziraat Fakültesi Yay., No: 12. Ders Notları Serisi No: 6. Tokat.

Dellal, G., Eliçin, A., Erkuş, A., Dellal, İ., Keskin, G., Tekel, N., 2001. GAP bölgesinde küçükbaş hayvan yetiştiriciliğinin yapısal özellikleri, ekonomik analizi ve hayvansal ürünlerin pazara arzı. TÜBİTAK, Ankara.

Dellal, G., Eliçin, A., Tekel, N., Dellal, İ. 2002. GAP bölgesinde küçükbaş hayvan yetiştiriciliğinin yapısal özellikleri. Tarım ve Köyişleri Bakanlığı Tarımsal Ekonomi Araştırma Enstitüsü, Yayın No: 82, Ankara.

Dönmez, O., 2008. Bursa ili koyunculuk işletmelerinin yetiştiricilik açısından yapısı. Yüksek Lisans Tezi. Namık Kemal Üniversitesi Fen Bilimleri Enstitüsü, Tekirdağ.

Karakaya, E., Kızıloğlu, S., 2014. Küçükbaş hayvancılık işletmelerinin örgütlenme yapısı Bingöl ili örneği.Türk Tarım ve Doğa Bilimleri Dergisi,1(4): 552-560.

Karakuş, F.,Akkol, S., 2013. Van ili küçükbaş hayvancılık işletmelerinin mevcut durumu ve verimliliği etkileyen sorunların tespiti üzerine bir araştırma. Yüzüncü Yıl Üniversitesi Fen Bil. Enst. Derg., 18 (1-2):09-16.

Karadaş, K., 2018a. Şanlıurfa ilinde koyunculuk işletmelerinin sosyo-ekonomik durumu: Siverek ilçesi örneği. GÜFBED/GUSTIJ (Araştırma/Research), 7 (2): 268-279.

Karadaş, K., 2018b. Koyunculuk işletmelerinin sosyo-ekonomik durumu; Hakkâri ili örneği. Atatürk Üniv. Ziraat Fak. Derg., 49 (1): 29-35. 
Koyuncu, E., Pala, A., Savaş, T., Konyalı, A., Ataşoğlu, C., Daş, G., Ersoy, İ.E., Uğur, F., Yurtman, İ.Y., Yurt, H.H., 2006. Çanakkale koyun ve keçi yetiştiricileri birliği üyesi keçicilik işletmelerinde teknik sorunların belirlenmesi üzerine bir araştırma. Hayvansal Üretim Derg., 47 (1): 21-27.

Paksoy, S., Atılgan, A., Akyüz, A., Kumova, Y., 2006. Kahramanmaraş yöresi koyunculuk işletmelerinin yapısal yönden mevcut durumları ve geliştirilmesi üzerine bir araştırma Süleyman Demirel Üniversitesi Ziraat Fakültesi Derg., 1 (2): 17-27.

Şahinli, M.A., 2014. Koyunculuk sürü yönetimi: Karaman ili örneği. Anadolu Tarım Bilim. Derg., 29 (2): 113-120.
Şişman C.B., Yılmaz F., Gezer E., 2009. Bolu Yöresindeki Küçükbaş Hayvan Barınaklarının Yapısal Durumu ve Geliştirme Olanakları. Tekirdağ Ziraat Fakültesi Dergisi, 6 (2): 179-189.

Tamer, B., Sarı̈zkan, S., 2017. Yozgat Merkez İlçede Koyunculuk Yapan İsletmelerin Sosyo-Ekonomik Yapısı ve Üretim Maliyetleri. Erciyes Üniv. Vet. Fak. Derg. 14 (1): 49-47.

Yamane, T., 2010. Temel örnekleme yöntemleri. Literatür Yayıncıllk. İstanbul.

Yazıcıŏ̆lu, E., Erdoğan, S., 2004. SPSS uygulamalı bilimsel araştırma yöntemleri. Detay Anatolia Akademik Yayıncılık. 1. Baskı. Ankara. 